\title{
Early Childhood Education and Its Correlation with Crime: A Review
}

\author{
Anwar Anwar ${ }^{1}$, \& Tatum Derin ${ }^{2}$ \\ ${ }^{1}$ Vocational High School 7 Pekanbaru, Indonesia \\ ${ }^{2}$ U-Raise Academy, Pekanbaru, Indonesia \\ derintatum@gmail.com
}

\section{ARTICLE HISTORY \\ Received : 2019-06-03 \\ Revised : 2019-06-20 \\ Accepted : 2019-07-12}

\section{KEYWORDS}

Early childhood education Criminal activities

Disadvantaged families

Gender

\begin{abstract}
This article reviews the new evidence offered by Jorge Luis García, James J. Heckman and Anna L. Ziff's paper entitled "Early Childhood Education and Crime." The paper showcased the impact of crime reduction from high-quality intensive early childhood programs. Its distinct advantage from other similar research attempts is it's long-term follow-up. The data collected were evaluated by randomized controlled trials, and this present article is interested in reviewing the results using a descriptive qualitative method. It is found, proportionally, more women than men reduce their criminal activities after participating in this program. Gender influences the experiences, giving a difference because the home environment of disadvantaged families that are mainly benefited by this program is typically worse for girls. This program of educating children with the particular purpose of shaping their morality and understanding of good and bad gives a suitable scope for better improvement by the program. For both sexes, the effect of treatment is greater for disadvantaged children, as measured by the education given by their mothers.
\end{abstract}

\section{Introduction}

Three scholars from different universities (Jorge Luis García, James J. Heckman and Anna L. Ziff) published a 9-page article entitled Early childhood education and crime as a follow-up to analyze crime in early childhood. All three are from the Department of Economics, and each has an interest in the early childhood field. García has at least four years of research experience dealing with early childhood development and education, with the earliest work done together with Heckman (Elango et al., 2015), a Nobel-prize-winning economist who was more experienced in gender difference, early childhood development, and labour economics research. Ziff's research track record is harder to find, and in the end, this study only found two papers under her name which are collaborative works with the other two authors (Garcia et al., 2018).

Early childhood education program investigates whether an influential and widely emulated it reduced involvement in the crime. Early childhood education promotes self-control and reduces externalizing behaviour. This is an important mediator to reduce involvement in criminal behaviour (Blackwell \& Piquero, 2005; Heckman, Pinto, \& Savelyev, 2013).

This article contributes to the reduction of criminalization involvement in early childhood with its Perry's Preschool Program that reduces violent crime between boys (Heckman, Moon, Pinto, Savelyev, \& Yavitz, 2010). The program reduces involvement in crime for both males and females, but more so for females, who have a lower baseline rate of crime participation. Early childhood education promotes self-control. One of the main benefits of the Preschool Program, Perry reduces violent crime among boys (Heckman, Moon, Pinto, Savelyev, \& Yavitz, 2010).

This research is very good for review because children were enrolled in this centre-based program at eight weeks of age until the first stage of the program ended at age five years children participated in both studies was born highly disadvantaged families in the Chapel Hill area. Early childhood program starting at eight weeks and continuing through age five years, on the criminal activity of participants.

They analyze crime in ABC/CARE the program Perry's Preschool. They Analyze data collected from the subject in the ABC/CARE programme evaluated by randomized controlled trial (RCT). This data combines the Carolina Abecedarian Project (ABC) and the Carolina Approach to Responsive Education (CARE). The goal of ABC/CARE was to promote language and cognitive development. To this end, the centre-based curriculum encouraged interactions between teachers and students (Sparling \& Lewis, 1979, 1984).

This article demonstrates sharp gender differences in responses to early childhood education in terms of crime averted for disadvantaged boys and girls. Treatment effects are more often statistically significant for girls than for boys at conventional levels. While the program benefits females more 
regarding the number of criminal outcomes with positive treatment effects and positive and significant treatment effects, the dollar values of crimes averted for men are much higher. The results are consistent with García, Heckman, and Ziff (2018), who reported that at baseline, girls are at a greater socioeconomic disadvantage so that the program has greater scope for improving girls' lives. The program is most effective for the most disadvantaged children of both genders.

\section{Findings}

The article study uses a qualitative approach. This is especially the case for crime, which is primarily committed during and after puberty (Moffitt, 1993). This research using the crime data, collected through both self-reports and administrative records. Administrative data on arrests and sentences are available at age 34 for subjects in ABC and CARE. At age 21 in $A B C$, we have data on the type of crime committed: violent, property, drug, or other. Selfreported data on offenses are collected at ages 21 and 34 for both $\mathrm{ABC}$ and CARE because the data capture crimes committed outside of North Carolina or unreported crimes while the administrative data can fill in gaps from underreporting in the self-reports using manual match. Therefore, this research makes the Program has self-reported and administrative data on crime outcomes collected when the subjects are adults. While other randomised studies of programs have larger samples and multisite designs, few programs currently have longitudinal data that facilitate analysing how early childhood education causally reduces criminal activity (Elango, García, Heckman, \& Hojman, 2016).

The first finding is that the intensive early childhood program is much more effective on girls than boys and the reason is uncovered to be because girls have worse home environment which becomes better after they participate in the program. Gender difference in crime is a regular thing (Rowe et al., 1995). Females were most likely to be victims of domestic homicides and sex-related homicides (Cooper \& Smith, 2012). According to another study about crime and sex difference, one of the reasons females have lower rates of offending is because they acquire social cognitive skills earlier in life than males do and because they have better prosocial skills (Bennett et al., 2005). So the authors were correct when they say that the girls gained more benefit from this program than the boys did.

This finding is also supported by the fact that men commit more crime than women consistently (Carrabine et al., 2014) and in crimes dealing with injury and death, men do them more than women apparently (Rowe et al., 1995). For children, the Center for Sex Offender Management indicates that approximately one-fifth of all rapes and one-half of all sexual child molestation can be accounted for by juveniles (Hunter et al., 1999).
Another famous and common topic to delve into crime reduction study is on the category of privilege. The author's research used a mother's education as a baseline and concluded that the program's effect on underprivileged students is more effective. There is a study that found that full-day program reduces youth crime because the increased adult supervision decreases the likelihood of girls or boys engaging in risky behaviour, and this is particularly effective for children in poor families (Berthelon et al., 2011). Education is important to prevent and reduce crime in children (Weston, 1939).

\section{Strengths and Weaknesses}

This article may be particularly notable because it provides new evidence of the long history of crime reduction study. It gives the treatment in the form of an intensive early childhood program with long-term follow-up, so that means this article is a lot more thorough than most studies that limit themselves to the aftermath of particular programs that the authors are bold enough to claim that their data is new evidence.

The environment better for boys, so the programs we study have greater coverage to improve the lives of girls because it makes Preschool Program Perry. While the program benefits females more regarding the number of criminal outcomes with positive treatment effects and positive and significant treatment effects, the dollar values of crimes averted for men are much higher. Our results are consistent with García, Heckman, and Ziff (2018), who reported that at baseline, girls are at a greater socioeconomic disadvantage so that the program has greater scope for improving girls' lives. There is a possible weakness in the research design for it does not use parental inputs, it is possible that other investments, such as early childhood education, have certain components that affect boys and girls differently. The children's skills imply out comes of interest that could have social factors influencing the subsequent skill formation differently for males and females. This fact leads to a better environment for boys so that the program that we study has a greater scope for improving girls' lives. Apart from parental inputs, it is possible that other investments, such as early childhood education, have certain components that affect boys and girls differently. Magnuson et al. (2016) provided a discussion of some of the components of centre-based education, such as gender in particular, that could differently affect boys and girls. For example, Holmlund and Sund (2008) reported that teachers respond more positively to children of the same sex.

\section{ABC/CARE Program}

$\mathrm{ABC}$ Care is a nonprofit corporation meant for school-age childcare centres. This program, "All Because Of Christ," is a school childcare program that is designed for students, held before and after school. 
ABC Care hours are from 7:15 a.m. until 8:05 a.m. before school. After school hours are from 3:15 p.m. through 6:00 p.m., Non-students are also welcome to attend the ABC program activities. ABC/CARE program is meant to provide a safe, secure, fun recreational and educational experience, and it seems that one of their missions is to prevent children from going to the path of crime by using an intervention program in during early childhood development. The after-school environment allows youth to interact among themselves and with adults in a more relaxed atmosphere.

Research shows that youth with the opportunity to build positive peer and adult relationships have better school and community connectedness, better school attendance, increased social competence, and less substance abuse and behavioural issues including gang involvement. School attendance and school connectedness are the single most important protective factors identified with reducing risky behaviours including substance abuse (alcohol, tobacco, and marijuana), acting out in class, fighting, bullying, and emotional distress. Research also indicates that after-school programs can markedly increase engagement in learning, improve academic achievement, and reduce behavioural issues.

The limit of this study is that most of the information about the ABC/CARE program is taken from Heckman's papers as the professor seems to be highly invested in the fruits of this program, so there is a possibility of bias. Other people have also noted that the paper is consistent with Heckman's other writings, so there is huge selection bias and apparently, zero acknowledgements of the problem (Andrew, 2017). But this may be understandable because, the fact is, the Abecedarian, and also Perry preschool studies while we're at it, are vastly overrepresented in the early childhood literature because they are the only studies that combine both high-quality study design (randomized treatment) with high quality, expensively collected long term follow up data. To my knowledge, alternative studies of the effects of early childhood education are based on either (a) more recent, better-designed studies with larger sample sizes and randomized treatment assignment, but very short term or low quality follow up information, e.g. the Head Start Impact Study or (b) much worse designed studies with long term follow up information, e.g. the Chicago Longitudinal Study. To point out their overrepresentation in the literature without acknowledging this seems unfair. Furthermore, both studies have so many papers on them in part because there has been a new wave of papers every time new data has become available (which has happened many times as more follow-ups were conducted).

In this 2019 paper, the authors mentioned that they have analysed data collected from subjects in the $\mathrm{ABC} / \mathrm{CARE}$ program evaluated by randomized controlled trial (RCT), which findings are in line with a study they conducted last year (Garcia et al., 2018), which data is in line with a study they did two years ago (Garcia et al., 2017). However, while they certainly elaborated how the program may reduce the possibility of crime conducted by male and female, it does not thoroughly explain the entirety of the program's approach beyond starting at birth and empowering parents with quality child care. Searching for Heckman's personal publicized document about the program, this study found the quality early childhood program is comprised of these nine elements:

(1) Starting at birth. Children were voluntarily enrolled by their parents as early as eight weeks old and remained with the program until they entered kindergarten, allowing them to build skill upon skill and preparing them for greater success in school and, ultimately, in life;

(2) Providing continuous care. The program was fulltime and intensive, with children spending eight to nine hours a day in centre-based care, five days a week, 50 weeks a year for five years.

(3) Engaging parents. Parents play the most critical role in developing skills and abilities in their children; therefore, the program provided parental education on building family life that is most conducive to the success of their children.

(4) Incorporating health as an input. A doctor and two nurses were on staff to provide developmentally appropriate screenings for health and wellness. Children who were identified as having health- or development-related problems were referred to local medical care, with the centre's doctors and nurses following up with the children and their parents to ensure medical compliance.

(5) Recognizing the importance of nutrition. All the children came from economically disadvantaged families where food security could be a problem. Understanding that a hungry child is least apt to learn, nutritious meals and snacks were provided while the children were in the center.

(6) Developing a full range of skills. A highly developmental approach was taken to advance early learning, with a focus on developing comprehensive skills through social-emotional and cognitive development. While one programmatic goal was to increase IQ and school readiness, the program acted on evidence that social and emotional skills drive cognitive achievement and, ultimately, life success.

(7) Empowering parents with quality child care. Reliable, high-quality child care provided parents with the confidence and means to enter into the workforce, build their skills, advance careers and acquire higher wages. The economic benefits of 
the additional wages earned by parents alone paid for the cost of the program after only five years.

(8) Transitioning children into elementary schooling. The program monitored the progress of its children during the first few years of elementary schooling, helping children successfully transition from a highly nurturing early childhood environment to potentially less nurturing public schools.

(9) Combining highly trained educators with welltrained and supervised teachers. ABC/CARE was developed, implemented and supervised by early childhood thought leaders and professionals who trained teachers and staff on how to identify with children, build relationships through empathy, create engagement, monitor progress and create continuous improvement.

\section{Conclusion}

This article gives present a program to improve education and reduce crime for demonstrates sharp gender differences in responses to early childhood education in terms of crime averted for disadvantaged boys and girls. Treatment effects are more often statistically significant for girls than for boys at conventional levels. While the program benefits females more regarding the number of criminal outcomes with positive treatment effects and positive and significant treatment effects, the dollar values of crimes averted for men are much higher. Our results are consistent with García, Heckman, and Ziff (2018), who reported that at baseline, girls are at a greater socioeconomic disadvantage so that the program has greater scope for improving girls' lives. The program is most effective for the most disadvantaged children of both genders.

\section{Acknowledgements}

The authors thank the anonymous reviewers for their fruitful comments for this research.

\section{References}

Anderson, D. A. (2012). The cost of crime. Foundations and Trends in Microeconomics, 7(3), 209-265.

Anderson, M. L. (2008). Multiple inferences and gender differences in the effects of early intervention: A reevaluation of the Abecedarian, Perry Preschool, and Early Training Projects. Journal of the American statistical association, 103(484), 1481-1495.

Andrew. (2017). How does a Nobel-prize-winning economist become a victim of bog-standard selection bias? Stat Modeling.

Bennett, S., Farrington, D. P., \& Huesmann, L. R. (2005). Explaining gender differences in crime and violence: The importance of social cognitive skills. Aggression and violent behaviour, 10(3), 263-288.

Berthelon, M. E., \& Kruger, D. I. (2011). Risky behaviour among youth: Incapacitation effects of school on adolescent motherhood and crime in Chile. Journal of public economics, 95(1-2), 4153.

Blackwell, B. S., \& Piquero, A. R. (2005). On the relationships between gender, power control, self-control, and crime. Journal of Criminal Justice, 33(1), 1-17.

Blackwell, B. S., \& Piquero, A. R. (2005). On the relationships between gender, power control, self-control, and crime. Journal of Criminal Justice, 33(1), 1-17.

Campbell, F. A., Conti, G., Heckman, J. J., Moon, S. H., Pinto, R., Pungello, E. P., \& Pan, Y. (2014). Early childhood investments substantially boost adult health. Science, 343(6178), 1478-1485.

Carrabine, E., Cox, P., Fussey, P., Hobbs, D., South, N., Thiel, D., \& Turton, J. (2014). Criminology: A sociological introduction. Routledge.

Cooper, A., \& Smith, E. L. (2012). Homicide trends in the United States, 1980-2008 (pp. 536-543). BiblioGov.

Efastri, S. M. (2018). Pendekatan Behavioural Dengan Teknik Social Modelling Untuk Mengurangi Perilaku Tempertantrum Pada Anak Usia Dini Kec. Tandun Kabupaten Rokan Hulu Riau. PAUD Lectura: Jurnal Pendidikan Anak Usia Dini, 2(01), 40-48.

Elango, S., García, J. L., Heckman, J. J., \& Hojman, A. (2015). Early childhood education. In Economics of Means-Tested Transfer Programs in the United States, Volume 2 (pp. 235-297). University of Chicago Press.

Garcia, J. L., Heckman, J. J., \& Ziff, A. L. (2018). Gender differences in the benefits of an influential early childhood program. European economic review, 109, 9-22.

García, J. L., Heckman, J. J., Leaf, D. E., \& Prados, M. J. (2017). Quantifying the life-cycle benefits of a prototypical early childhood program (No. w23479). National Bureau of Economic Research.

Gross, R. T., Spiker, D. \& Haynes, C. W. (eds). (1997). Helping low birth weight, premature babies: the infant health and development program. Stanford, CA: Stanford University Press.

Heckman, J. J., \& Karapakula, G. (2018). Designspecific inference of treatment effects: Understanding the long-term impact of high quality targeted preschool. Chicago, IL: 
University of Chicago, Department of Economics.

Heckman, J. J., \& Karapakula, G. (2018). Designspecific inference of treatment effects: Understanding the long-term impact of high quality targeted preschool. Chicago, IL: University of Chicago, Department of Economics.

Heckman, J. J., Moon, S. H., Pinto, R., Savelyev, P. A., \& Yavitz, A. Q. (2010a). Analyzing social experiments as implemented: A reexamination of the evidence from the High Scope Perry Preschool Program. Quantitative Economics, 1(1), 1-46.

Hunter, J., Carter, M. M., \& Matson, S. (1999). Understanding juvenile sexual offending behavior: Emerging research, treatment approaches and management practices. Washington, DC: Center for Sex Offender Management.

Ramey, C. T., \& Campbell, F. A. (1979). Compensatory education for disadvantaged children. the school review, 87(2), 171-189.

Ramey, C. T., \& Campbell, F. A. (1984). Preventive education for highrisk children: Cognitive consequences of the Carolina Abecedarian Project. AmericanJournalofMentalDeficiency, 88(5), 515-523.

Reswita, R. (2017). Hubungan pola asuh orangtua dengan capaian perkembangan anak. Paud Lectura: Jurnal Pendidikan Anak Usia Dini, 1(1), 72-81.

Rowe, D. C., Vazsonyi, A. T., \& Flannery, D. J. (1995). Sex differences in crime: Do means and within-sex variation have similar causes?. Journal of Research in Crime and Delinquency, 32(1), 84-100.

Wahyuni, S., Reswita, R., \& Filtri, H. (2018). Subjective Well-Being Anak Yang Berasal Dari Keluarga Berstatus Ekonomi Sosial Rendah. Lectura: Jurnal Pendidikan, 9(2), 149-160. https://doi.org/10.31849/lectura.v9i2.1605

Weston, H. E. (1939). The Role of the School in Crime Prevention. YB, 28. 